\title{
Effect of crop management intensity on energy and carbon dioxide balance of two bioenergy Sorghum bicolor hybrids
}

\author{
Antonio M. Cabrera-Ariza, ${ }^{1}$ Cristiano Tozzini, ${ }^{2}$ Sergio E. Espinoza-Meza, ${ }^{3}$ \\ Rómulo E. Santelices-Moya, ${ }^{3}$ Carlos R. Magni-Díaz, ${ }^{4}$ Máximo F. Alonso-Valdés 5 \\ ${ }^{1}$ Vice-rectorate for Research and Postgraduate Studies, Centro del Secano, the Catholic University of Maule, \\ Chile; ${ }^{2}$ Scuola Superiore Sant'Anna, Pisa, Italy; ${ }^{3}$ Centro del Secano, the Catholic University of Maule, \\ Chile; ${ }^{4}$ Department of Forestry and Nature Conservation, University of Chile, Chile; ${ }^{5}$ Institute of Animal \\ Production, Austral University of Chile, Chile
}

\begin{abstract}
Although bioenergy sorghum has many traits that make it ideal for biofuel production, management conditions that can affect the productivity and sustainability of these systems are still poorly understood. This paper estimated the energy and $\mathrm{CO}_{2}$ balance of two bioenergy sorghum (Sorghum bicolor L. Moench.) hybrids (H128 and H133) cultivated during two growing seasons and under two different levels of crop management, high and low input. At the end of both growing season, sorghum was harvested for biomass yield determination. Calorific value and net energy production were also estimated. Crop management had important effects on sorghum $\mathrm{CO}_{2}$ and energy balance. The energy produced varied between 126 and $365 \mathrm{GJ}^{-1}$ depending on crop management, hybrid and growing season. Regarding of the $\mathrm{CO}_{2}$ balance, the high level of crop management had a superior $\mathrm{CO}_{2}$ emission. However, the energy produced per $\mathrm{kg}$ of $\mathrm{CO}_{2}$ emitted was higher $(>300 \%)$ than the energy produced with the use of fossil fuels. The use of bioenergy sorghum can contribute to better energy sustainability and reduced $\mathrm{CO}_{2}$ emission in Mediterranean ecosystems.
\end{abstract}

Correspondence: Antonio María Cabrera-Ariza, Vice-rectorate for Research and Postgraduate Studies, Centro del Secano, the Catholic University of Maule, Avenida San Miguel 3605, Talca, Chile.

Tel.: +56.71.2413728. E-mail: acabrera@ucm.cl

Key words: Biomass; greenhouses gases; low-input system; high-input system; fertilisation.

Contributions: AC, CT, data collecting and analysing; AC, RS, SE, manuscript writing; CM, MA, manuscript reviewing.

Conflict of interests: the authors declare no potential conflict of interests.

Received for publication: 29 August 2018.

Revision received: 31 August 2018.

Accepted for publication: 21 November 2018.

(C) Copyright A.M. Cabrera-Ariza et al., 2018

Licensee PAGEPress, Italy

Italian Journal of Agronomy 2019; 14:1316

doi:10.4081/ija.2018.1316

This article is distributed under the terms of the Creative Commons Attribution Noncommercial License (by-nc 4.0) which permits any noncommercial use, distribution, and reproduction in any medium, provided the original author(s) and source are credited.

\section{Introduction}

Renewable sources are contributing in meeting energy requirements with the added advantage of greater environmental protection, especially in terms of carbon dioxide $\left(\mathrm{CO}_{2}\right)$ emissions (Monti and Ventura, 2003). In this context, biomass is a promising renewable energy source. An important challenge related to the use of alternative crops for energy production is quantifying the environmental sustainability of these crops in the long term (Bonari et al., 1992). For this purpose, energy and $\mathrm{CO}_{2}$ balances represent appropriate tools for the evaluation of such sustainability. It is accepted that the energy obtained from biomass has not carbon emissions associated because the carbon emitted in its combustion is the same that plants absorbed while growing (Royal Society, 2008). Thus, the energy produced by energy crops must be higher than the energy required to produce them, to have a positive energy balance (Scholz and Ellerbrock, 2002). The energy balance shows the energy produced per unit of energy used in the process of production and transformation of biomass into electrical energy (Sartori et al., 2005). This balance has been widely used in different studies (Bonari et al., 1992; Dubuisson and Sintzoff, 1998; West and Marland, 2002; Heller et al., 2003; Sartori et al., 2005; Mead and Pimentel, 2006; Boehemel et al., 2008; Gasol et al., 2009; Nassi o di Nasso et al., 2010). On the other hand, $\mathrm{CO}_{2}$ balance has also been used (Lewandowski et al., 1995; Cannell, 2002; Kaur et al., 2002; Hoosbeek et al., 2006) for evaluating sustainability. It estimates the emissions generated in the whole crop production cycle and compared them to the $\mathrm{CO}_{2}$ fixed by the plant during its growth. $\mathrm{CO}_{2}$ balance takes into account all the issues arising from field operations and considers not only the emissions produced during the combustion of the biomass, but also the emissions generated by the production inputs (fertilisers, herbicides, etc.).

There is a wide range of woody and herbaceous species used to produce energy from biomass. Bioenergy sorghum (Sorghum bicolor $\mathrm{L}$. Moench) is among the most promising herbaceous species as it is considered a multifunctional crop (Lynd et al., 1991; Ding, et al., 2017) due that it can provide a wide range of products, like sugars, alcohol, syrups, biofuels, paper, and food. This crop has low input requirements, is drought tolerant, has a great yield stability under a wide range of environmental conditions (Miller and Mcbee, 1993; Buxton et al., 1999; Wight et al., 2012; Amatya et al., 2014; Ameen et al., 2017), and does not directly compete with food crops because thanks to its short growing cycle it can be cultivated in rotation with winter food crops (Garofaldo et al., 2016). Besides, the crop is used to obtain biofuel due to its high quantity of carbohydrates. Given the remarkable work of selection done with this 
species (El Bassam, 1998), sorghum has a large spectrum of varieties. Among them we can find sweet sorghums, forage sorghums, grain sorghums, scope sorghums and fibre sorghums. The latter, considered hybrids between grain and scope sorghums (El Bassam, 1998). These hybrids are characterised by internodes rich in fibre and are used for the production of biomass for energy purposes. Bioenergy sorghum is an herbaceous annual crop of high yield easy to incorporate in ordinary crop rotations (Berenguer and Faci, 2001). The species is a C4 metabolism plant, returning 4-5 units of energy for every unit of energy used. $\mathrm{C} 4$ plants are one of the most efficient in converting solar energy into biomass (Lewandowski et al., 1995). Previous studies have already shown the potential of sorghum as a source of biomass, obtaining positive results in the energy balance and showing a significant reduction in $\mathrm{CO}_{2}$ emissions with respect to the use of fossil fuels. For example, Ding et al. (2017) has concluded that sweet sorghum straw-based ethanol has advantages in terms of energy consumption, with a well to wheel decrease of $85 \%$ fossil energy and $44 \%$ global warming potential, as compared with gasoline. Cai et al. (2013) concluded that grain sorghum-based ethanol could reduce well-to-wheels greenhouse gas (GHG) emissions when wet or dried distillers grains with solubles is the co-product and fossil natural gas is consumed as the process fuel. Although bioenergy sorghum has many traits that make it ideal for biofuel production, management conditions that can affect the productivity and sustainability of these systems are still poorly understood. The objective of this paper is to analyse the effect of crop management intensity (high and low input) on $\mathrm{CO}_{2}$ and energy balance of two bioenergy sorghum hybrids (H128 and H133) cultivated during two consecutive growing seasons.

\section{Materials and methods}

\section{Study area}

The study was conducted at Centro di Ricerche Agro-ambientale (CIRRA) Enrico Avanzi at Pisa University (Italy). The experimental field is situated in San Piero a Grado, $43^{\circ} 40^{\prime} \mathrm{N}$ and $10^{\circ} 21^{\prime}$ $\mathrm{E}$ at $5 \mathrm{~m}$ above sea level and $2 \mathrm{~km}$ far from the sea. The soil was a
Xerofluvent (clay $20.1 \%$, silt $40.5 \%$, sand $39.4 \%$ ), typical of the lower River Arno, which is an alluvial plain characterised by a superficial water table ( $1.8 \mathrm{~m}$ deep in the driest conditions) and good nutrient availability (organic matter $1.8 \%$, total nitrogen content $1.3 \mathrm{~g} \mathrm{~kg}^{-1}$, available phosphorus $8.8 \mathrm{mg} \mathrm{kg}^{-1}$ and exchangeable potassium $128.3 \mathrm{mg} \mathrm{kg}^{-1}$ ). The previous crop was wheat. Figure 1 shows average climatic conditions site during the trial.

\section{Experimental design}

Sorghum experiments were carried out through two different levels crop management, high input (HI) and low input (LI). In both treatments, we utilised two sorghum hybrids: H128, early maturing hybrid; and H133, an early-medium hybrid, both of them are fibre sorghums. The trial was set up on plots of $2000 \mathrm{~m}^{2}$ with a total area of $12.000 \mathrm{~m}^{2}$. The experiment was set up as a $2 \times 2$ Latin square where the treatments where the hybrid (H128 vs H133) and the crop management level (HI vs LI). In the first season, both hybrids were planted on April 10, 2006. The harvest was made on September 15, 2006. In the second season (2007), the planting took place on April 8 and the harvest on September 14.

High input: The study was conducted from April 2006 to midSeptember 2007 during two consecutive growing seasons. Weed control was carried out using the herbicide Pendimentalin ${ }^{\circledR}$ with a dose of $0.51 \mathrm{ha}^{-1}$ followed by a subsoiling. A plowing was also provided. The seeding was performed using precision pneumatic seeders (Damax ${ }^{\circledR}$ PNL Mt. 4) placing the seed at a depth of 20 $\mathrm{mm}$, in a density of 20 plants per square meter $(0.25 \mathrm{~m}$ row spacing, $0.2 \mathrm{~m}$ within the row, $13 \mathrm{~kg}$ seed $\left.\mathrm{ha}^{-1}\right)$. As regards the fertilisation, the doses used were $70 \mathrm{~kg} \mathrm{ha}^{-1}$ of urea [32.2 $\mathrm{kg}$ of nitrogen (N)] and $80 \mathrm{~kg} \mathrm{ha}^{-1}$ of triple superphosphate [36.8 $\mathrm{kg}$ of phosphorous $(\mathrm{P})]$ in pre-sowing, and $90 \mathrm{~kg} \mathrm{ha}^{-1}$ of urea after sowing (panicle initiation stage, approximately 32 days after emergence). The final harvest was done with a mowing-propelled forage harvester (Claas Jaguar 870) in mid-September, 10-20 days before flowering stage, at maximum dry matter accumulation and cellulose content in the plant (Peyre, 1979). Once the crop was harvested, a soil restoration with a subsoiling was done.

Low input: The differences regarding HI management were as follows: i) plowing was not carried out after subsoiling; ii) fertilis-
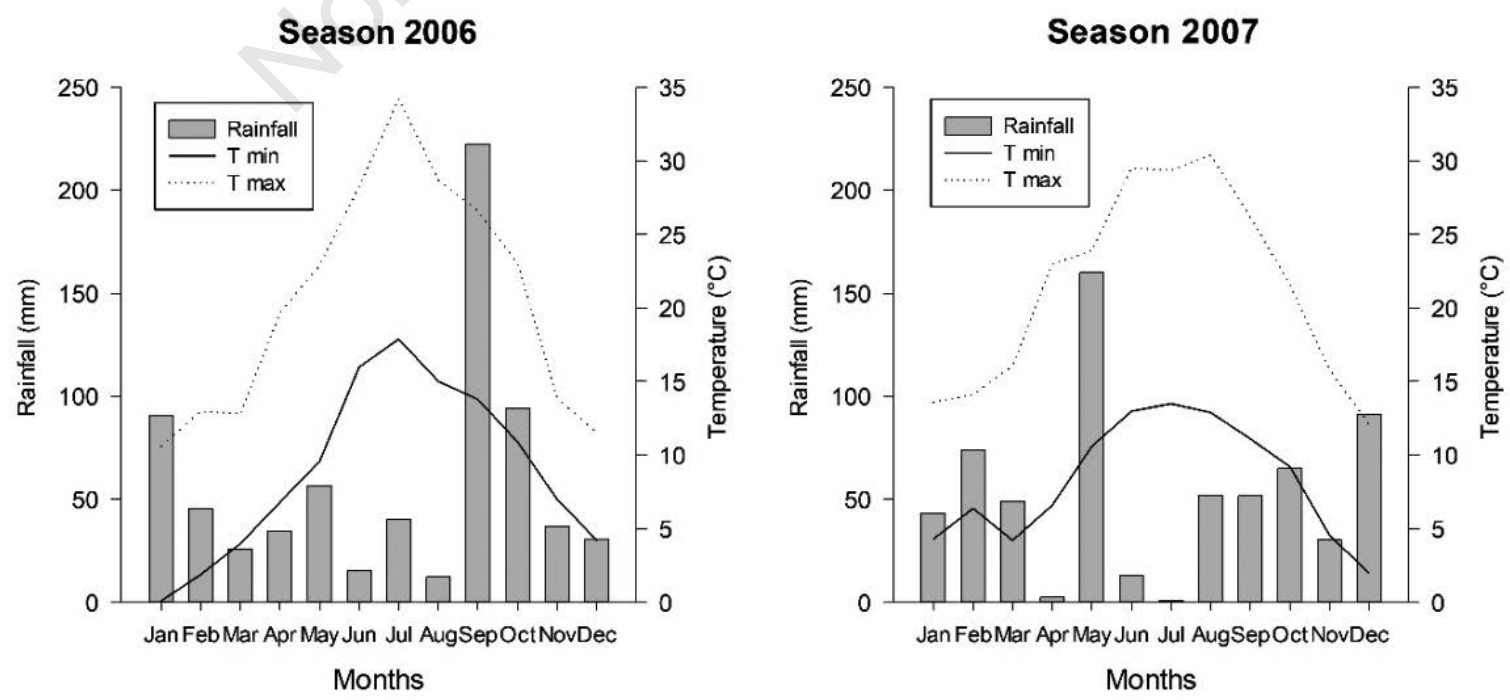

Figure 1. Average climatic conditions at the field experimental station in growing season 2006 and 2007. T min, minimum temperature; $\mathrm{T}$ max, maximum temperature. 
er doses used were $40 \mathrm{~kg} \mathrm{ha}^{-1}$ of urea and $50 \mathrm{~kg} \mathrm{ha}^{-1}$ of triple superphosphate in pre-sowing and $60 \mathrm{~kg} \mathrm{ha}^{-1}$ of urea after sowing. All the others operations were exactly the same.

Above-ground biomass production was estimated by manual cutting and sampling of four replicates of $10 \mathrm{~m}^{2}$ randomly taken from each experimental field. Approximately $6 \mathrm{~kg}$ from each biomass sample was weighed, dried at $105^{\circ} \mathrm{C}$ until reaching a constant mass, and re-weighed to calculate dry matter content. Samples have been taken with a monthly frequency since June in order to observe the development in plant biomass. To avoid border effects, were chosen the plants growth under regular cultivation shade excluding external lines of the parcel. Student's $t$-test at $\mathrm{P}=1 \%$ was used to compare biomass yield of different treatments. The data related to each sorghum sampling were subjected to statistical analysis using the CoStat program version 6.205, submitting all the data to a completely randomised two-way block ANOVA analysis, where the factors analysed were the level of crop management and the hybrid employee. The statistical significance of the differences between the averages was analysed with the Student's $t$-test for $\mathrm{P} \leq 0.01$, performed only on those parameters that were significant for the analysis of variance.

\section{Energy balance}

This study considered the flows of energy associated to the operations necessary for the sorghum cultivation, excluding the energy required to transport the biomass from field to the electric power plant, and then for the conversion of biomass into electricity.

The energy input required for sorghum cultivation was estimated considering the energy costs for manufacturing and maintaining agricultural machinery (tractor and tools), fertilisers and herbicides production and fuel and oil consumption in the various crop operations.

It was assumed that the tractors and equipments have been used in 200 ha and have a useful life of 10 years. Energy costs for building, maintenance and depreciation of tractors were estimated taking into account the useful life. These were then converted into amounts of energy through appropriate coefficients found in international scientific literature produced on this topic (Table 1). The energy production of the system (output) was determined by multiplying the dry matter biomass yield by the calorific value of the biomass calculated using the Mahler bomb calorimeter (ASTM D2015). Subsequently, we calculated the net energy production (output - input) and the energy efficiency (output/input).

The net energy production was calculated as follows (Eqs. 1-3):

Net energy production [GJ ha-1]= Energy produced [GJ ha-1] Energy consumed [GJ ha ${ }^{-1}$ ]

where:

Energy produced $\left[\mathrm{GJ} \mathrm{ha}^{-1}\right]=$ Calorific value $\left[\mathrm{GJ} \mathrm{Mg}^{-1}\right] \times$ biomass yield $\left[\mathrm{Mg} \mathrm{DB} \mathrm{ha} \mathrm{ha}^{-1}\right]$

Energy consumed $\left[\mathrm{GJ} \mathrm{ha}^{-1}\right]=$ Energy of operations $\left[\mathrm{GJ} \mathrm{ha}^{-1}\right]+$ Energy of production factors [GJ ha-1]

where, DB means dry biomass.

We created a database to determine the energy used in performing each of the farming operations (Table 2). We itemised direct and indirect energy costs of different operations, being direct cost those related to the cost of the specific operations, while indirect costs are related to the energy cost for the construction of machinery, equipment and implements. Most of the data presented in Table 2 are part of Sisco software, developed for calculating energy balances at Enrico Avanzi Centre (Bonari et al., 1999). Other coefficients were calculated by measuring fuel consumption of tractors in different farming operations at field trials.

\section{$\mathrm{CO}_{2}$ balance}

Data on fuel and oil consumption was taken from International Panel on Climate Change (ICPP, 2006). According to this source, the emissions generated by one kilogram of fuel and one kilogram of oil are $3.19 \mathrm{~kg}$ of $\mathrm{CO}_{2}$ and $2.95 \mathrm{~kg}$ of $\mathrm{CO}_{2}$, respectively. $\mathrm{CO}_{2}$ emissions generated by other agricultural inputs (fertilisers, herbicides, etc.) were calculated with data from West and Marland (2002) (Table 3). Specific consumption for farming operations was obtained from Bonari (1999), for similar operations (Table 4) at the same areas. Data regarding to the harvest was determined directly during the experiment.

\section{Results}

\section{Climatic behaviour}

During the experimentation period, the hottest month was July with an average temperature of over $21^{\circ} \mathrm{C}$ and with maximum values even above $30^{\circ} \mathrm{C}$. The 2006 season was characterised by a rather harsh winter in which the minimum temperatures from

Table 1. Energy equivalent used in this study and the respective source.

\begin{tabular}{lccc} 
Unit of & $\begin{array}{c}\text { Bnergy } \\
\text { equivalent }\end{array}$ & Reference \\
Machine & $\mathrm{MJ} \mathrm{kg}^{-1}$ & 108 & Kalk and Hulsbergen, 1996 \\
Fuel & $\mathrm{MJ} \mathrm{l}^{-1}$ & 42.7 & Bohemel et al., 2008 \\
\hline Oil & $\mathrm{MJ} \mathrm{l}^{-1}$ & 80 & Bonari et al., 1992 \\
$\mathrm{N}$ & $\mathrm{MJ} \mathrm{kg}^{-1}$ & 47.1 & Acaraglu and Semi, 2005 \\
\hline $\mathrm{P}_{2} \mathrm{O}_{5}$ & $\mathrm{MJ} \mathrm{kg}^{-1}$ & 15.8 & Kaltschmitt et al., 1997 \\
Herbicides & $\mathrm{MJ} \mathrm{kg}^{-1}$ & 276 & West and Marland, 2002 \\
\hline
\end{tabular}

$\mathrm{N}$, nitrogen; $\mathrm{P}_{2} \mathrm{O}_{5}$, triple superphosphate.

Table 2. Direct and indirect energy used in farming operations and inputs.

\begin{tabular}{|c|c|c|c|c|}
\hline Operation & Tractor (Kw) & $\begin{array}{l}\text { Consumed } \\
\text { Direct }\end{array}$ & $\begin{array}{l}\text { energy (1 } \\
\text { Indirect }\end{array}$ & $\begin{array}{l}\text { J ha }^{-1} \text { ) } \\
\text { Total }\end{array}$ \\
\hline Plow & 132 & 1500 & 479 & 1979 \\
\hline Subsoiling & 73 & 332 & 308 & 640 \\
\hline Fertilisation & 48 & 334.6 & 161 & 495.6 \\
\hline Weeding & 48 & 303 & 164 & 467 \\
\hline Sowing sorghum & 48 & 661.6 & 210 & 871.6 \\
\hline Sorghum harvest & 132 & 884 & 624 & 1508 \\
\hline Sorghum seed $\left(\mathrm{MJ} \mathrm{kg}^{-1}\right)$ & & 59.5 & & 59.5 \\
\hline $\mathrm{N}\left(\mathrm{MJ} \mathrm{kg}^{-1}\right)$ & & 47.1 & & 47.1 \\
\hline $\mathrm{P}_{2} \mathrm{O}_{5}\left(\mathrm{MJ} \mathrm{kg}^{-1}\right)$ & & 7.03 & & 7.03 \\
\hline Herbicide (MJ L ${ }^{-1}$ ) & & 138 & & 138 \\
\hline
\end{tabular}

$\mathrm{N}$, nitrogen; $\mathrm{P}_{2} \mathrm{O}_{5}$, triple superphosphate. $\mathrm{N}$, nitrogen; $\mathrm{P}_{2} \mathrm{O}_{5}$, triple superphosphate. 
January to March were more than a degree lower than the longterm values, while the summer temperatures of July exceeded $34^{\circ} \mathrm{C}$ and those of September and October respectively $26^{\circ} \mathrm{C}$ and $23^{\circ} \mathrm{C}$. In 2007 , the winter months of January and February were mild, while in the summer the hottest month, unlike the other years was that of August with temperatures above $30^{\circ} \mathrm{C}$.

Rainfall distribution was similar in both years, which were characterised by heavy rains in the autumn months and droughts in the months of July and August. However, the annual rainfall was characterised by lower values than the long-term one $(940 \mathrm{~mm})$, recording $705 \mathrm{~mm}$ in 2006 and $632 \mathrm{~mm}$ in 2007.

\section{Biomass production}

As expected, HI treatment yielded higher dry biomass than LI treatment for both hybrids and growing seasons under study (Figure 2). However, hybrid H128 was more responsive to the HI management in season 2006, while hybrid H133 had a superior yield in HI management in 2007. A significant difference between the two levels of cultivation intensity was identified in 2006, with HI treatment being the most productive. In 2007, the situation was comparable to 2006, with significant differences between the two levels of crop intensification at harvest time (averaging $20.7 \mathrm{Mg}$ $\mathrm{ha}^{-1}$ for HI $v_{s} 14.4 \mathrm{Mg} \mathrm{ha}^{-1}$ for LI, respectively). On the other hand, no significant differences were observed regarding to the different hybrids in either of the two experimental years. In addition, there was not a significant hybrid $\times$ management interaction. It is important to note that the great difference in biomass yield between 2006 and 2007 it was mainly due to the low percentage of plant survival in the first year of experimentation.

\section{Energy balance}

Table 5 shows calorific value for hybrid sorghums, growing seasons and level of crop management under study. In general, no statistical differences were observed.

The total energy cost for growing sorghum was $45 \%$ higher in the HI treatment $\left(16.04 \mathrm{GJ} \mathrm{ha}^{-1}\right)$ with respect to the LI treatment
Table 3. Conversion factors for $\mathrm{CO}_{2}$ emissions of different inputs according to West and Marland (2002).

\begin{tabular}{lc} 
Inputs & Conversion factor $\left(\mathrm{kg} \mathrm{CO}_{2} \mathrm{~kg}^{-1}\right)$ \\
$\mathrm{N}$ & 3.15 \\
$\mathrm{P}_{2} \mathrm{O}_{5}$ & 6.04 \\
\hline Herbicide & 15.92 \\
Sorghum seed & 3.15 \\
\hline
\end{tabular}

$\mathrm{CO}_{2}$, carbon dioxide; $\mathrm{N}$, nitrogen; $\mathrm{P}_{2} \mathrm{O}_{5}$, triple superphosphate.

Table 4. Fuel and oil consumption of different agricultural operations and its related $\mathrm{CO}_{2}$ emissions.

\begin{tabular}{lccc} 
Operation & $\begin{array}{c}\text { Diesel } \\
\left(\mathrm{kg} \mathrm{ha}^{-1}\right)\end{array}$ & $\begin{array}{c}\text { Oil consumption } \\
\left(\mathrm{kg} \mathrm{ha}^{-1}\right)\end{array}$ & $\begin{array}{c}\mathrm{CO}_{2} \text { emissions } \\
\left(\mathrm{kg} \mathrm{CO}_{2} \mathrm{ha}^{-1}\right)\end{array}$ \\
Plow & 50 & 0.20 & 180.4 \\
Subsoiling & 14.6 & 0.04 & 46.5 \\
\hline Fertilisation & 7.8 & 0.02 & 24.9 \\
Weeding & 10.9 & 0.06 & 34.7 \\
\hline Sowing sorghum & 11.9 & 0.05 & 37.9 \\
Sorghum harvest & 20.6 & 0.10 & 65.7 \\
\hline
\end{tabular}

$\mathrm{CO}_{2}$, carbon dioxide.

Table 5. Calorific value of $\mathrm{H} 128$ and $\mathrm{H} 133$ sorghum hybrids in 2006 and 2007 at two levels of crop intensification (high and low inputs).

\begin{tabular}{lcc} 
Sorghum hybrid & \multicolumn{2}{c}{ Calorific value $\left(\mathrm{MJ} \mathrm{kg}^{-1}\right)$} \\
2006 & 2007 \\
H128 HI & $16.9^{\mathrm{a}}$ & $16.7^{\mathrm{A}}$ \\
H128 LI & $18.4^{\mathrm{a}}$ & $18.4^{\mathrm{A}}$ \\
\hline H133 HI & $17.7^{\mathrm{a}}$ & $17.0^{\mathrm{A}}$ \\
H133 LI & $17.2^{\mathrm{a}}$ & $17.0^{\mathrm{A}}$ \\
\hline
\end{tabular}

Values having a common letter are not significantly different at P-level=1\%; lowercase is for season 2006 , uppercase is for season 2007. HI, high input; LI, low input.
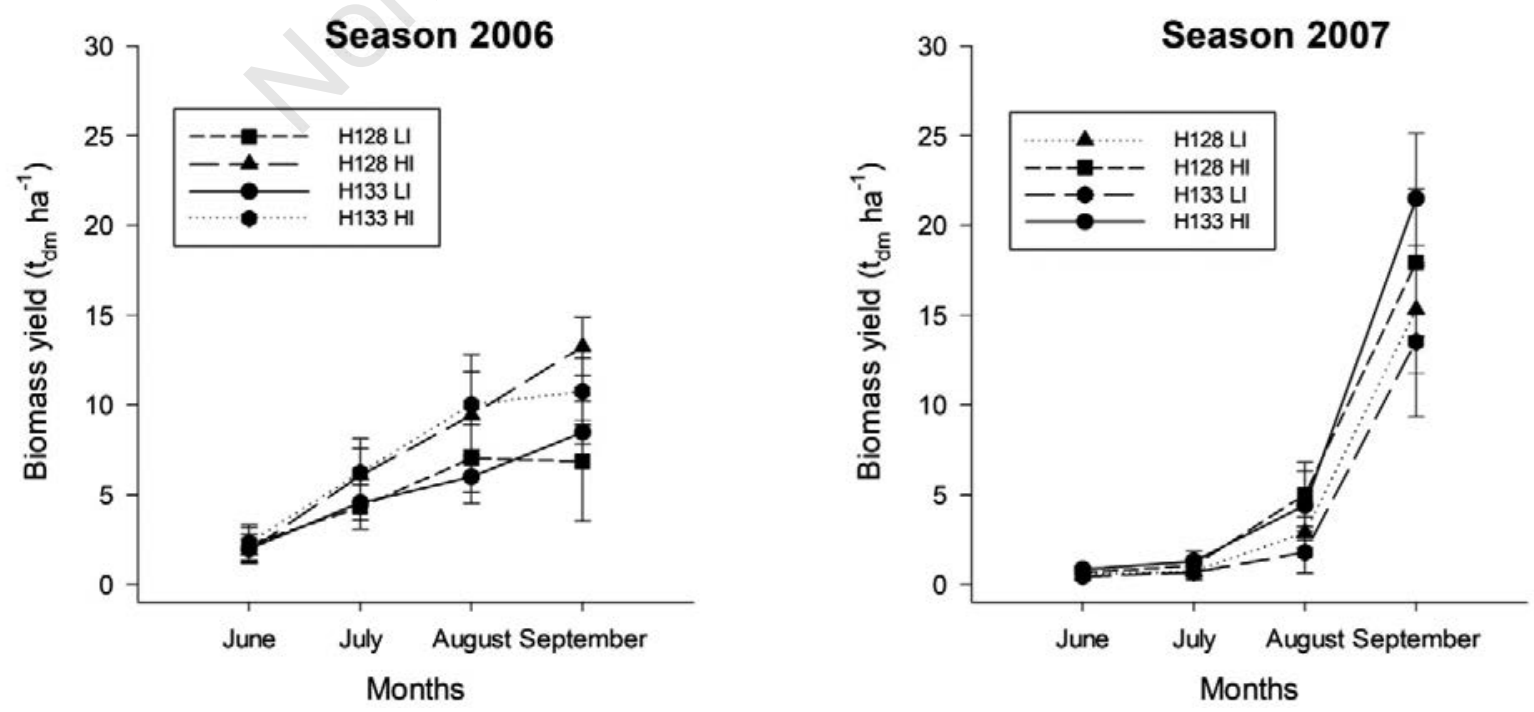

Figure 2. Dry biomass of H128 and H133 sorghum hybrids under two different levels of intensification in 2006 and $2007 . \mathrm{HI}$, high input; LI, low input. 
(11.02 $\left.\mathrm{GJ} \mathrm{ha}^{-1}\right)$. The overall energy cost was related to fertilisation, which represents $56.7 \%$ of the total cost in HI and $54.9 \%$ in LI treatments. There were no significant differences between the hybrids so in Table 6 it is shown the energy balance for the mean of the two sorghum hybrids at two different levels of crop management (HI) and (LI), during the growing seasons 2006 and 2007. In addition, there was no statistical interaction between the hybrid and the level of crop management.

The output showed significant differences between the two levels of crop management analysed with a mean increment of $68.7 \%$ and $88.1 \%$ in HI and LI respectively from 2006 to 2007 , mainly due to the low percentage of plant survival in the first year of experimentation and the consequent lower energy output. Comparing the output value for the two levels of crop intensification adopted, our results showed that the average for both hybrids at HI yielded a higher amount of energy than at LI in both years, with $207.1 \mathrm{GJ} \mathrm{ha}^{-1}$ vs $136.04 \mathrm{GJ}^{-1}$ in 2006 and $349.33 \mathrm{GJ} \mathrm{ha}^{-1}$ vs $255.94 \mathrm{GJ} \mathrm{ha}^{-1}$ in 2007 . However, the behaviour showed was always the same for both years, with values slightly higher for H128 than H133 but with no statistical differences between them. As regards the net energy produced by the system (output-input), there were no statistical differences between the two hybrids, nevertheless an average difference of $34.56 \%$ and $22.73 \%$ between HI and LI during the two growing seasons respectively. Consequently, analysing the energy efficiency of the system, results showed a better performance in 2007 due to the higher production of biomass.

\section{$\mathrm{CO}_{2}$ balance}

Table 7 shows the emissions associated with crop operations for the production of bioenergy sorghum in $\mathrm{HI}$ and LI treatments. As expected, $\mathrm{HI}$ crop management system has $60.73 \%$ higher $\mathrm{CO}_{2}$ emissions than LI crop management. Obviously, the advantage in term of GHG saving in the LI treatment was a consequence of reduced diesel consumption for the field operations and the $\mathrm{N}$ fertilisation. At this point it is important to note that most of the carbon emissions are due to fertilisation, representing $62.41 \%$ and $63.24 \%$ respectively for $\mathrm{HI}$ and LI.

\section{Discussion}

\section{Biomass production}

Regarding the number of plants per unit area, it is important to notice that it had been severely compromised in the 2006 season due to seed predation by the entomofauna. Probably, on the emergency rate it also affected the water stagnation that occurred in some study areas. In fact, with a sowing dose of 20 seeds $\mathrm{m}^{-2}$, at a distance of about one month from sowing, the average percentage of emergency was as follows:

- LI: 46\% (about 9 plants $\mathrm{m}^{-2}$ ) emergency in H128 hybrid, and $43 \%$ emergency (about 8 plants $\mathrm{m}^{-2}$ ) in $\mathrm{H} 133$.

- HI: hybrid H128 emergency of $34 \%$ against $33 \%$ of the hybrid H133 (for both about 6 plants $\mathrm{m}^{-2}$ ).

In contrast, in 2007 the number of plants emerged was, on average, 13 plants $\mathrm{m}^{-2}$ for both hybrids. This is $65 \%$ emergency.

The study of the trend of biomass accumulation in the 2006 and 2007 growth seasons (Figure 2) shows that in the first year of experimentation the growth of fibre sorghum was constant until August for both level of crop management. From August to September the biomass accumulation remains constant in the HI and increase in the LI. season. In contrast, in the 2007 growth sea- son, the accumulation of biomass was very low until August, while a strong increase in the development of plants was recorded between August and September. Statistically significant differences were identified in relation to the level of crop intensification only in the month of August and in correspondence with the harvest (September) for both years of experimentation. This, given the same trend observed for the two compared hybrids, could depend on a different strategy of response of the crop to the climatic conditions. In fact, in 2006 the summer season from June to July was characterised by rains for $55.4 \mathrm{~mm}$, while in the same time frame in 2007 were recorded only $13.8 \mathrm{~mm}$ of rainfall which results in a

Table 6. Energy balance for the mean of two hybrids of sorghum (H128 and H133) made at two different levels of crop management (high and low inputs), during the growing seasons 2006 and 2007.

\begin{tabular}{|c|c|c|c|c|c|c|}
\hline \multirow[t]{2}{*}{ Year } & \multicolumn{2}{|c|}{$\begin{array}{l}\text { Output } \\
\left(\text { GJ ha }^{-1}\right)\end{array}$} & \multicolumn{2}{|c|}{$\begin{array}{l}\text { Net energy } \\
\text { production } \\
\left(\mathrm{GJ} \mathrm{ha} \mathrm{ha}^{-1}\right)\end{array}$} & \multicolumn{2}{|c|}{$\begin{array}{l}\text { Energy } \\
\text { efficiency }\end{array}$} \\
\hline & HI & LI & HI & U & HI & L \\
\hline 2006 & $207.10^{a}$ & $136.04^{b}$ & $191.06^{\mathrm{a}}$ & $125.02^{\mathrm{b}}$ & $12.91^{\mathrm{a}}$ & $12.34^{b}$ \\
\hline 2007 & $349.33^{\mathrm{A}}$ & $255.94^{\text {B }}$ & $316.96^{\mathrm{A}}$ & $244.92^{B}$ & $21.78^{\mathrm{A}}$ & $23.22^{\mathrm{B}}$ \\
\hline
\end{tabular}

Values having a common letter are not significantly different at $\mathrm{P}$-level=1\%; lowercase is for season 2006 , uppercase is for season 2007. HI, high input; LI, low input.

Table 7. $\mathrm{CO}_{2}$ emissions of cropping sorghum with high and low input.

\begin{tabular}{lcc} 
Operations & \multicolumn{2}{c}{$\mathrm{CO}_{2}$ emissions $\left(\mathrm{kg} \mathrm{CO}_{2} \mathrm{ha}^{-1}\right)$} \\
HI & - \\
Plow & 180.4 & 93 \\
Subsoiling & 93 & 49.8 \\
\hline Fertilisation & 49.8 & 34.7 \\
Weeding & 34.7 & 37.9 \\
\hline Sowing sorghum & 37.9 & 65.7 \\
Sorghum harvest & 65.7 & 40.95 \\
\hline Sorghum seed & 40.95 & 130.41 \\
$\mathrm{~N}$ & 231.84 & 302 \\
\hline $\mathrm{P}_{2} \mathrm{O}_{5}$ & 483.2 & 7.96 \\
Herbicide & 7.96 & 762.42 \\
\hline Total & 1225.45 &
\end{tabular}

$\mathrm{CO}_{2}$, carbon dioxide; $\mathrm{N}$, nitrogen; $\mathrm{P}_{2} \mathrm{O}$, triple superphosphate; $\mathrm{HI}$, high input; LI, low input.

Table 8. Energy produced per kg of $\mathrm{CO}_{2}$ emitted with $\mathrm{H} 128$ and H133 sorghum hybrids at high and low level of intensification versus fossil fuels.

\begin{tabular}{|c|c|c|c|}
\hline \multicolumn{2}{|c|}{ Energy source } & \multicolumn{2}{|c|}{ MJ Produced per kg of $\mathrm{CO}_{2}$ emitter } \\
\hline $\mathrm{H} 128$ & $\begin{array}{l}\text { HI } \\
\text { LI }\end{array}$ & $\begin{array}{l}169.6 \\
151.1\end{array}$ & $\begin{array}{l}258.6 \\
355.0\end{array}$ \\
\hline H133 & $\begin{array}{l}\mathrm{HI} \\
\mathrm{LI}\end{array}$ & $\begin{array}{l}142.2 \\
176.9\end{array}$ & $\begin{array}{l}285.3 \\
287.5\end{array}$ \\
\hline \multicolumn{2}{|c|}{ Coal* } & \multicolumn{2}{|c|}{73.3} \\
\hline \multicolumn{2}{|c|}{ Fuel Motor* } & \multicolumn{2}{|c|}{54.5} \\
\hline \multicolumn{2}{|c|}{ Natural Gas* } & \multicolumn{2}{|c|}{72.9} \\
\hline \multicolumn{2}{|c|}{ Kerosene* } & \multicolumn{2}{|c|}{53.5} \\
\hline
\end{tabular}

${ }^{*}$ www.eia.gov Official Energy Statistics from the U.S. Government; $\mathrm{CO}_{2}$, carbon dioxide; $\mathrm{N}$, nitrogen; $\mathrm{P}_{2} \mathrm{O}_{5}$, triple superphosphate; HI, high input; LI, low input. 
lower biomass accumulation. As we have already anticipated previously at the time of collection, a statistically significant difference was found between the two different levels of crop management, being the $\mathrm{HI}$ the most productive against $7.67 \mathrm{t} \mathrm{ha}^{-1}$ of the LI. In 2007, the situation was completely similar, with statistically significant differences between the two different levels of crop management at the time of harvest $\left(20.7 \mathrm{t} \mathrm{ha}^{-1}\right.$ for $\mathrm{HI} v s 14.4 \mathrm{ha}^{-1}$ for LI). This may be due to the higher amount of potassium, since nitrogen, according to other authors (Garofalo et al., 2015, 2016), is not a key element in terms of biomass production. For example, Ceotto et al. (2014) who indicated that the productivity of sorghum under nitrogen 0 treatment was comparable to that for partial and fully fertilised sorghum even after 5 years. Moreover, there were not statistically significant differences with respect to the two different hybrids during the two years of experimentation.

Our results corroborated that the level of crop management and the year of cultivation exerted important effects on sorghum biomass production. In other studies, sorghum yield values were similar to those obtained in our study, the variation is mainly due to the irrigation doses. For example, Curt et al. (1998) in a trial conducted in Spain, obtained yields from 18 to $48 \mathrm{t} \mathrm{ha}^{-1}$ depending on 4 different doses of irrigation. Hallam et al. (2001), in a study conducted in Iowa (USA), proposed different doses of fertilisation for yields ranging from 15.3 to $20.7 \mathrm{t} \mathrm{ha}^{-1}$. Habyarimana et al. (2004) carried out an experiment in Italy on sorghum, applying different irrigation water amount on several hybrids with crop yield ranging from 20 to $51 \mathrm{t} \mathrm{ha}^{-1}$. In a study carried out in northern Italy, Barbanti et al. (2006) proposed different doses of fertiliser in fibre and sweet sorghum with yield ranging from 17.7 to $24.2 \mathrm{t} \mathrm{ha}^{-1}$. Giovanardi et al. (2008), in the Friulian plain (Italy) using hybrids of irrigated sorghum obtained yields varying between 19 and $40 \mathrm{t}$ $\mathrm{ha}^{-1}$. Zhao et al. (2009) conducted a trial in Beijing (China) with 5 different sorghum hybrids and testing different irrigation doses obtained yields from 13.2 to $35.2 \mathrm{tha}^{-1}$.

\section{Energy balance}

The results indicate a better performance in the HI energy balance. The difference between treatments is basically due to the higher biomass production, since in the other variables there have not been significant differences. Results obtained in the second year of the trial confirm those reported in previous publications (Lewandowski et al., 1995; Monti et al., 2003). Monti et al. (2003), obtained input values of $15.9 \mathrm{MJ} \mathrm{ha}^{-1}$ with an energy efficiency of 23. In other studies conducted on annual crops for energy use, the ratio output/input ranges from 13 to 39 (Venturi and Venturi, 2003). In herbaceous perennial crops such as miscanthus or common reed, output/input ratio were 30 and 40, respectively (Ercoli et al., 1999; Angelini et al., 2005), while the biomass produced from conventional forestry had energy efficiency values between 10-25 (Mead and Pimentel, 2006).

The hybrid choice in this study was not relevant. What was relevant was the level of intensification utilised, obtaining higher yields with a higher level of crop intensification. Most of the energy consumption was mainly due to the fuel and $\mathrm{N}$ production and use. Thus, reducing the contribution of these inputs led to a significant decline in the energy consumption. Other authors observed a significant energy saving was achieved by reducing soil tillage and $\mathrm{N}$ application, with improvement in energy balance and efficiency of energy crops (Liebam et al., 2008). In any case, an economic analysis should be done to evaluate if the investment required in the high level of intensification is justified with the sale of biomass.

\section{$\mathrm{CO}_{2}$ balance}

$\mathrm{CO}_{2}$ emissions of the production of $\mathrm{HI}$ sorghum were higher than those of LI $(-37.2 \%)$, and considering the emissions the low input would be the most convenient alternative. The most impacting factors on the GHG emissions ( $\mathrm{N}$ and fuel consumption for the crop management) are also the easiest to modulate, so if we want to reduce emissions, we must act on these two factors, mainly. In a review of different energy crops Cosentino et al. (2008) obtained emission values that ranged between 18.9 and 33 tons of $\mathrm{CO}_{2} \mathrm{ha}^{-}$ 1. Their values were higher than those obtained in the present study because they analysed the complete cycle of energy production, including the biomass conversion process. The values for the $\mathrm{CO}_{2}$ emissions of this study could be compared to those obtained in studies of corn, barley and soybean. Borin et al. (1997) in a study that include experimental tests carried out with different levels of crop intensification obtained values that vary between 2.336 and $3.05 \mathrm{Mg} \mathrm{ha}^{-1} \mathrm{yr}^{-1}$ of $\mathrm{CO}_{2}$. Further testing, such as that achieved by Dornburg et al. (2005), reported emission values of hemp and wheat ranging from 1.56 to $3.1 \mathrm{Mg} \mathrm{ha}^{-1} \mathrm{yr}^{-1}$ of $\mathrm{CO}_{2}$, respectively.

Table 8 shows a comparison of carbon emissions for the energy production with fossil fuels and sweet sorghum under the reported cropping systems. Even though, emissions will arise if consider the sugar-bioethanol conversion process, it is clear that the latter alternative is much more affordable than using fossil fuels.

\section{Conclusions}

Based on results of this study it can be concluded that energy cropping systems based on sorghum can contribute in reducing greenhouse gas emissions, specifically through the adoption of low intensification cropping systems. We can conclude that the cultivation of the H128 and H133 hybrids of sorghum has a positive energy balance. In terms of biomass, there are no significant differences by the clone chosen, but there are significant differences by the type of crop management used, being the intensive management the most productive. In terms of energy balance, the intensive crop management yields more energy than LI management, but there are no significant differences between the performances observed in the two hybrids. In terms of $\mathrm{CO}_{2}$ emissions, LI management produced fewer emissions than the high input management. Today, an issue to consider is that these types of crops can compete with food crops, in that case, the goal is to achieve the greatest energy return from a cropped unit to fulfil energy demands. However, when there are no limits in the land available, the level of crop management with the higher energy efficiency should be preferred, to achieve improved energy output with reduced fossil energy use during the crop cycle. Thus, the use of renewable energy sources such as sorghum biomass can effectively contribute to a better energy sustainability through reducing greenhouse gases emissions. Nevertheless, further studies on energy and $\mathrm{CO}_{2}$ balances of biomass sources as fuel are needed.

\section{References}

Acaraglu M, Semi A, 2005. The cultivation and energy balance of Miscanthus $\times$ giganteus production in Turkey. Biomass Bioenerg. 29:42-8.

Amatya P, Wight J, Mjelde J, Hons F, 2014 Balancing bioenergy 
and soil productivity returns for sustainable biomass sorghum [Sorghum bicolor (L). Moench.] Production. Bioenerg. Res. 7:1144-54

Ameen A, Yang X, Chen F, Tang C, Du F, Fahad S, Xie G, 2017. Biomass yield and nutrient uptake of energy sorghum in response to nitrogen fertiliser rate on marginal land in a semiarid region. Bioenerg. Res. 10:363-76.

Angelini G, Ceccarini L, Nassi o Di Nasso N, Bonari E, 2005. Long term evaluation of biomass production of giant reed (Arundo donax L.) to different fertilisation input, plant density and harvest time in a Mediterranean environment. pp 141-144 in Proceeding of $14^{\text {th }}$ European Biomass Conference and Exhibition, Paris, France.

ASTM (American Society for Testing and Materials), 2015. ASTM D2015: Gross calorific value of solid fuel by the adiabatic bomb calorimeter. Available from: https://archive.org/details/ gov.law.astm.d2015.1996

Barbanti L, Grandi S, Vecchi A, Venturi G, 2006. Sweet and fibre sorghum (Sorghum bicolor (L.) Moench), energy crops in the frame of environmental protection from excessive nitrogen loads. Eur. J. Agron. 25:30-9.

Berenguer MJ, Faci JM, 2001. Sorghum (Sorghum bicolor (L.) Moench) yield compensation processes under different plant densities and variable water supply. Eur. J. Agron. 15:43-55.

Boehmel C, Lewandowski I, Claupein W, 2008. Comparing annual and perennial energy cropping systems with different management intensities. Agr. Syst. 96:224-36.

Bonari E, Peruzzi A, Mazzoncini M, Silvestri N, 1992. Valutazione energetiche di sistemi produttivi a diverso livello di intensificazione colturale. Inf. Agr. 1:11-25.

Bonari E, Silvestri N, Pampana S, 1999. Sisco: a pratical tool to assess alternative cropping systems' performances. pp 285 in International Symposium Modelling, Cropping Systems, Lleida, Spain.

Borin M, Menini C, Sartori L, 1997. Effects of tillage systems on energy and carbon balance in north-eastern Italy. Soil Till. Res. 40:209-26.

Buxton DR, Anderson IC, Hallam A, 1999. Performance of sweet and forage sorghum grown continuously, double-cropped with winter rye, or in rotation with soybean and maise. Agron. J. 91:93-101.

Cannell M, 2002. Carbon sequestration and biomass energy offset: theoretical, potential and achievable capacities globally, in Europe and the UK. Biomass. Bioenerg. 24:97-116.

Cai H, Dunn J, Wang Z, Han J, Wang M, 2013. Life-cycle energy use and greenhouse gas emissions of production of bioethanol from sorghum in the United States. Biotechnol. Biofuels. 6:141.

Ceotto E, Castelli F, Moschella A, Diozzia M, Di Candilo M, 2014. It is not worthwhile to fertilise sweet sorghum (Sorghum bicolour L. Moench) with cattle slurry: productivity and nitrogen-use efficiency. Ind. Crop Prod. 62:380-6.

Cosentino S, Copani V, Patanè C, Mantineo M, D’Agosta G, 2008. Agronomic, energetic and environmental aspects of biomass energy crops suitable for Italian environments. Ital. J. Agron. 3:81-95.

Curt MD, Fernández J, Martínez M, 1998. Productivity and radiation use efficiency of sweet sorghum (Sorghum bicolor (L.) Moench) cv. "Keller" in central Spain. Biomass. Bioenerg. 14:169-78.

Ding N, Yang Y, Caic H, Liu J, Ren L, Yang J, Guang HX, 2017. Life cycle assessment of fuel ethanol produced from soluble sugar in sweet sorghum stalks in North China. J. Clean. Prod.
161:335-44.

Dornburg V, Termeer G, Faaij APC, 2005. Economic and greenhouse gas emission analysis of bioenergy production using multi-product crops - case studies for the Netherlands and Poland. Biomass. Bioenerg. 28:454-74.

Dubuisson X, Sintzoff I, 1998. Energy and $\mathrm{CO}_{2}$ balances in different power generation routes using wood fuel from short rotation coppice. Biomass. Bioenerg. 15:379-90.

El Bassam N, 1998. Energy plant species: their use and impact on environment and development. James \& James Science Publishers, UK, pp. 334.

Ercoli L, Mariotti M, Masoni A, Bonari E, 1999. Effect of irrigation and nitrogen fertilisation on biomass yield and efficiency of energy use in crop production of Miscanthus. Field Crop Res. 63:3-11.

Garofaldo P, D’Andrea L, Vonella A, Rinaldi M, Palumbo A, 2015. Energy performance and efficiency of two sugar crops for the biofuel supply chain. Perspectives for sustainable field management in southern Italy. Energy 93:1548-57.

Garofalo P, D’Andrea L, Vonella A, Rinaldi M, Palumbo A, 2016. Sweet Sorghum in a bioetanol supply chain: effects of different soil and nitrogen management on energy performances and greenhouse gas emissions. Ital. J. Agrometeorol. 2:15-24.

Gasol C, Gabarrel X, Anton A, Rigola M, Carrasco J, Ciria P, Rieradevall J, 2009. LCA of poplar bionergy system compared with Brassica carinata energy crop and natural gas in regional scenario. Biomass. Bioenerg. 33:119-29.

Giovanardi R, Danuso F, Picco D, Ferro L, Tassan-Mazzocco G, Rosso S, Zuliani F, Castelluccio MD, 2008. Il sorgo da fibra: Bilancio energetico e aspetti ambientali nella pianura Friulana. Pre-Atti XIII Convegno Internazionale Interdisciplinare. Unicità, uniformità e universalità nella identificazione del mosaico paesistico-culturale, Aquileia (UD), Italy.

Habyarimana E, Laureti D, De Ninno M, Lorenzoni C, 2004. Performances of biomass sorghum [Sorghum bicolor (L.) Moench] under different water regimes in Mediterranean region. Ind. Crop Prod. 20:23-8.

Hallam A, Anderson IC, Buxton DR, 2001. Comparative economic analysis of perennial, annual and intercrops for biomass production. Biomass. Bioenerg. 21:407-24.

Heller M, Keoleian G, Volk T, 2003. Life cycle assessment of a willow bioenergy cropping system. Biomass. Bioenerg. 25:147-65.

Hoosbeek M, Li Y, Scarascia-Mugnozza G, 2006. Free atmospheric $\mathrm{CO}_{2}$ enrichment (FACE) increased labile and total carbon in the mineral soil of a short rotation poplar plantation. Plant Soil. 281:247-54.

ICPP (Intergovernmental Panel on Climate Change), 2006. Guidelines for National Greenhouse Gas Inventories. Intergovernmental Panel on Climate Change. Available from: https://www.ipcc-nggip.iges.or.jp/public/2006gl/

Kalk WD, Hulsbergen KJ, 1996. Methodik zur Einbeziehung des indirekten Energieverbrauchs mit Investitionsgutern in Energiebilanzen von Landwirtschaftsbetrieben. Kuhn-Arch. 90:41-56.

Kaltschmitt M, Reinhardt GA, Stelzer T, 1997. Life cycle analysis of biofuels under different environmental aspects. Biomass. Bioenerg. 12:121-34.

Kaur B, Gupta S, Singh G, 2002. Carbon storage and nitrogen cycling in silvopastoral systems on a sodic soil in northwestern India. Agroforest. Syst. 54:21-9.

Lewandowski I, Kicherer A, Vonier P, 1995. $\mathrm{CO}_{2}$-balance for the cultivation and combustion of Miscanthus. Biomass. Bioenerg. 8:81-90. 
Liebam M, Gibson LR, Sundberg DN, Heggenstaller AH, Westerman PR, Chase CA, Hartzler RG, Menalled FD, Davis AS, Dixon PM, 2008. Agronomic and economic performance characteristics of conventional and low-external-input cropping systems in Central Corn Belt. Agron J. 100:600-9.

Lynd LR, Cushman JH, Nichols RJ, Wyman CE, 1991. Fuel ethanol from cellulosic biomass. Science 251:1318-23.

Mead DJ, Pimentel D, 2006. Use of energy analysis in silvicultural decision-making. Biomass Bioenerg. 30:357-62.

Miller FR, Mcbee GG, 1993. Genetics and management of physiological systems of sorghum for biomass production. Biomass. Bioenerg. 5:41-9.

Monti A, Venturi G, 2003. Comparison of the energy performance of fibre sorghum, sweet sorghum and wheat monocultures in northern Italy. Eur J Agron. 19:35-43.

Nassi o Di Nasso N, Guidi W, Ragaglini G, Tozzini C, Bonari E, 2010. Biomass production and energy balance of a 12 -yearold short-rotation coppice poplar stand under different cutting cycles. GCB Bioenergy. 2:89-97.

Peyre B, 1979. Contribution a l'étude du sorgho papetier. Memoire de fin d'étud. Ecole Superieure Agronomique Pourpare. pp 114.
Royal Society, 2008. Sustainable biofuels: prospects and challenges. Policy document '1/08. London, UK.

Sartori L, Basso B, Bertocco M, Oliviero G, 2005. Energy use and economic evaluation of a three-year crop rotation for conservation and organic farming in NE Italy. Biosyst. Eng. 91:245-256.

Scholz V, Ellerbrock R, 2002. The growth productivity, and environmental impact of the cultivation of energy crops on sandy soil in Germany. Biomass Bioenerg. 23:81-92.

Venturi P, Venturi G, 2003. Analysis of energy comparison for crops in European agricultural systems. Biomass. Bioenerg. 25:235-55.

West TO, Marland G, 2002. A synthesis of carbon sequestration, carbon emissions, and net carbon flux in agriculture: comparing tillage practices in the United States. Agr. Ecosyst. Environ. 91:217-32.

Wight J, Hons F, Storlien J, Provin T, Shahandeh H, Wiedenfeld R, 2012. Management effects on bioenergy sorghum growth, yield and nutrient uptake. Biomass. Bioenerg. 46:593-604.

Zhao Y, Dolat A, Steinberger J, Wang X, Osman A, Xie G, 2009. Biomass yield and changes in chemical composition of sweet sorghum cultivars grown for biofuel. Field Crop Res. 111:55-64. 